\title{
PERANAN PENYIDIK DALAM TINDAK PIDANA PEMILIHAN KEPALA DAERAH
}

\author{
Rusmanto \\ Kepolisian Resort Pemalang \\ rusmanto412@gmail.com
}

\begin{abstract}
This research is about: The Role of the Police Investigators Handling Crime Election, aims to identify and analyze the role of police investigator in the handling of criminal acts in the elections. barriers faced by investigators in handling criminal acts of the local elections and how to overcome them. The method used juridical empirical. Data collected through interviews, documents and literature studies. The data were analyzed qualitatively. Police investigators role in the handling of criminal acts Selection of regional heads, namely as an investigator of the alleged criminal acts of the local elections. Handling of criminal acts carried out by the local election supervisory committee report after a discussion of the integrated role in law enforcement centers to report violations of the elections. There is a problem in penangana criminal election among other issues Money, Criminal policies should be done in full against certain acts, especially against a weak special crimes if applied to the Criminal Code which is the general criminal provisions, as well as the election of the offenses in addition to regulate acts that may be liable to criminal threat should be listed as well. It is important that the criminal policy can achieve the desired objectives. There should be attempts non penal more intensive in combating criminal election as money politics that still exists due to the weak criminal sanctions.
\end{abstract}

Keyword: Crime, Elections, Investigators

\section{A. Pendahuluan}

Kerangka negara demokrasi, pelaksanaan Pemilihan Umum (Pemilu) merupakan momentum yang sangat penting bagi pembentukan pemerintahan dan penyelenggaraan negara periode berikutnya. Pemilu,selain merupakan mekanisme bagi rakyat untuk 
memilih para wakil juga dapat dilihat sebagai proses evaluasi dan pembentukan kembali kontrak sosial. ${ }^{1}$ Salah satu konsekuensi yuridis dari sistem negara hukum yang demokratis di Indonesia adalah adanya pemlihan pemimpin dengan cara yang demokratis. Pemilihan pemimpin tersebut, termasuk pemilihan pemimpin di daerah atau biasa dikenal sebagai kepala daerah. ${ }^{2}$

Penyidik Polri merupakan salah satu penegak hukum yang mendapat tugas dan tanggung jawab menyelesaikan tindak pidana pemilihan di tingkat penyidikan.Secara umum tugas Polri dalam penyelenggaraan pemilu yaitu melakukan pengamanan pada setiap tahapan pelaksanaan pemilu, agar penyelenggaran pemilu dapat berjalan dengan aman dan lancar. Melakukan penyidikan terhadap tindak pidana pemilu yang dilaporkan kepadaPolri melalui bawaslu, panwaslu provinsi, panwaslu kabupaten/kota. Melakukan tugas lain menurut perundang-undangan yang berlaku, antara lain melakukan tugas pelayanan penerimaan pemberitahuan kegiatan kampanye dan atau pemberian, Ijin kepada peserta pemilu.

Proses penyidikan dilakukan oleh penyidik Polri dalam jangka waktu selama-lamanya 14 hari terhitung sejak diterimanya laporan dari Bawaslu. Jadi, 14 hari sejak diterimanya laporan dari Bawaslu, pihak penyidik harus menyampaikan hasil penyidikan beserta berkas perkara kepada Penuntut Umum Jika hasil penyidikan dianggap belum lengkap, maka dalam waktu paling lama tiga hari penuntut umum mengembalikan berkas perkara kepada penyidik kepolisian disertai dengan petunjuk untuk melengkapi berkas bersangkutan. Perbaikan berkas oleh penyidik maksimal tiga hari untuk kemudian dikembalikan

1 Djanedjri M, 2009, Pelanggaran dan Sengketa Pemilu, Harian Seputra Indonesia, Jakarta, h.. 1.

2 Sayyidatul Insiyahm Xavier Nugraha, Shevierra Danmadiyah, Pemilihan Kepala Daerah Oleh Dewan Perwakilan Rakyat Daerah: Sebuah Komparasi Dengan Pemilihan Secara Langsung Oleh Rakyat, Supremasi Hukum : Jurnal Penelitian Hukum, Vol. 28, No. 2, Agustus 2019, hlm.163-186. 
Kepada Penuntut Umum. Maksimal lima hari sejak berkas diterima, PU melimpahkan berkas perkara kepada pengadilan. Untuk memudahkan proses pemeriksaan terhadap adanya dugaan pelanggaran pidana Pemilu, Bawaslu, Kepolisian dan Kejaksaan telah membuat kesepahaman bersama dan telah membentuk sentra penegakkan hukum terpadu (Sentra Penegakkan Hukum Terpadu (Gakkumdu))

Proses peradilan pidana Pemilihan Umum (Pemilu) ditentukan hanya terdiri atas dua tingkat, tingkat pertama di pengadilan negeri dan tingkat banding di pengadilan tinggi. Putusan pengadilan tinggi merupakan putusan terakhir dan mengikat. Selain itu, khusus untuk pengadilan pelanggaran Pemilihan Umum (Pemilu) yang dapat mempengaruhi perolehan suara, ditentukan harus sudah selesai paling lama 5 hari sebelum Komisi Pemilihan Umum (KPU) menetapkan hasil pemilu secara nasional. ${ }^{3}$ Penanganan tindak pidana pemilu sama dengan tindak pidana umumnya, namun terkadang diperlukan penanganan-penanganan khusus, seperti pengamanan pelaku, maupun menjaga kondusifitas suasana pemilu.

\section{B. METOde PENELITIAN}

Metode pendekatan yang digunakan penelitian ini adalah metode pendekatan yuridis empiris. Pendekatan yuridis empiris merupakan penelitian terhadap fenomena empiris atau perilaku nyata masyarakat dalam penerapan hukum atau peraturan perundang-undangan. Penelitian yuridis empiris hendak meneliti penerapan peraturan perundang-undangan dalam praktik di lapangan.

Penelitian yuridis empiris juga dikenal dengan istilah sosio legal research atau penelitian lapangan. Pada pendekatan dilakukan penelitian lapangan untuk mengetahui jawaban terhadap pokok

${ }^{3}$ Ibid. 
permasalahan yang menjadi obyek penelitian. Penelitian ini hendak meneliti peranan penyidik Polres Pemalang dalam penanganan tindak pidana pemilihan kepala daerah di Pemalang tahun 2015.

\section{HASIL PENELITIAN DAN PEMBAHASAN}

\section{Peranan Penyidik dalam Tindak Pidana Pemilihan Kepala Daerah}

Untuk menjaga pemilu dari berbagai gangguan dan hambatan serta pelanggaran pidana maka dibentuk Sentra Penegakan Hukum Terpadu berdasarkan Kesepakatan Bersama antara Badan pengawas Pemilihan Umum Republik Indonesia, Kepolisian Negara Republik Indonesia dan Kejaksaan Republik Indonesia Nomor : 15/NKB/BAWASLU/X/2015, Nomor : B/38/X/2015 dan Nomor : KEP153/A/JA/2015 tentang Sentra Penegakan Hukum Terpadu. Pada Pasal 8 disebutkan bahwa dalam hal kajian awal pengawas atau pemilu atau laporan dan / atau temuan merupakan dugaan tindak pidana pemilu, pelamnggaran peimlu maka dilakukan pembahasan. Pembahasan berupa kesimpulan dapat berupa dugaan:

a. Tindak pidana Pemilu, pelanggaran pemilu Presiden dan Wakil Presiden dan tindak pidana pemilihan yang memenuhi syarat formil dan materiil.

b. Bukan tindak pidana, bukan pelanggaran pidana pemilu Presiden dan Wakil Presiden dan bukan tindak pidana pemilihan atau

c. Perbuatan melawan hukum lainn.

Di atas segalanya, kompleksitas dari penangkalan suap politik Pilkada sungguh dibenarkan bagi hakim untuk menjatuhkan pidana tambahan kepada Calon Kepala Daerah dan Partai Politik manakala telah terdapat pidana pokok (penjara atau denda). Sebab selain Undang-Undang Pemilihan Kepala Daerah, Pasal 153 ayat (2) junto Pasal 35 ke-3 KUHP juga memberi penegasan "dalam hal 
pemidanaan kejahatan (barang siapa memberi atau menjanjikan sesuatu, menyuap seseorang supaya tidak memakai hak pilihnya atau supaya memakai hak itu menurut cara tertentu) dapat dikenakan pidana pencabutan hak memilih dan dipilih dalam pemilihan yang diadakan berdasarkan aturan-aturan umum.

Peranan Penyidik Polres Pemalang dalam penanganan tindak pidana Pemilihan kepala daerah yaitu sebagai penyidik adanya dugaan tindak pidana pemilihan kepala daerah. Penanganan tindak pidana pemilihan kepala daerah dilaksanakan berdasarkan laporan panitia pengawas setelah melalui pembahasan dalan sentra penegakan hukum terpadu (Sentra Gakkumdu) terhadap laporan pelanggaran pemilihan kepala daerah.

Masalah ini penyidik dapat menggunakan ketentuan Pasal 150 KUHP yang menyatakan bahwa "Barang siapa pada waktu diadakan pemilihan berdasarkan aturan-aturan umum, melakukan tipu muslihat berdasarkan aturan-aturan umum, melakukan tipu muslihat sehingga suara seorang pemilih menjadi tidak berharga atau menyebabkan orang lain daripada yang dimaksud oleh pemilih yang ditunjuk, diancam dengan pidana penjara paling lama sembilan bulan."

Mencermati pada permsalahan pidana tersebut di atas kaitannya dengan sanksi pidana pada Undang-Undang Pemilihan Kepala Daerah 2015, maka apabila ditinjau dari ruang lingkup kebijakan hukum pidana dapat disimpulkan bahwa kebijakan mengenai tindak pidana pemilu kepala daerah masih sangat lemah. Artinya, masih terdapat perbuatan pidana yang bahkan tidak ada ancaman pidananya dalam Undang-Undang Pemilihan Kepala Daerah, pdahal undang-undang tersebut merupakan lex specialist atau peraturan perundangundangan yang di dalamnya mengatur tindak pidana khusus yaitu tindak pidana pemilu. 
Marc Ancel menyatakan bahwa penal policy (kebijakan hukum pidana), adalah suatu ilmu sekaligus seni yang pada akhirnya mempunyai tujuan praktis untuk memungkinkan peraturan hukum positif dirumuskan secara lebih baik dan untuk memberi pedoman tidak hanya kepada pembuat undang-undang, tetapi juga kepada pengadilan yang menerapkan undang-undang dan juga kepada para penyelenggara atau pelaksana putusan pengadilan. ${ }^{4}$

Secara umum politik hukum pidana merupakan upaya menentukan kearah mana pemberlakuan hukum pidana Indonesia ke masa yang akan datang dengan melihat penegakannya saat ini. Lebih lanjut Sudarto mengungkapkan bahwa pelaksanaan politik hukum pidana berarti mengadakan pemilihan dalam rangka mencapai hasil perundang-undangan pidana yang paling baik dengan memenuhi syarat-syarat keadilan dan dayaguna. ${ }^{5}$

Menurut Barda Nawawi Arief di dalam kebijakan hukum pidana, terdapat 2 (dua) masalah sentral yang mesti menjadi perhatian jika hukum pidana, inklusif sanksi pidana ingin dilibatkan yakni :6

1. Perbuatan apa yang seharusnya dijadikan tindak pidana; dan

2. Sanksi apa yang sebaiknya digunakan atau dikenakan kepada si pelanggar.

Ditegaskan oleh Barda Nawawi Arief, analisa terhadap masalah sentral ini tidak dapat dipisahkan dari konsepsi integral kebijakan kriminal dengan kebijakan sosial dan kebijakan pembangunan nasional. Artinya, pemecahan masalah-masalah di atas harus pula diserahkan untuk mencapai tujuan-tujuan tertentu dari kebijakan sosial yang telah ditetapkan. Dengan demikian, kebijakan hukum

${ }^{4}$ Barda Nawawi Arief 1996, Bunga Rampai Kebijakan Hukum Pidana, Citra Aditya Bakti, Bandung, h. 23

5Mahmud Mulyadi, 2006, Kebijakan Penanggulangan Kejahatan Kekerasan (Studi di Kota Palembang), Disertasi, h. 95

6Barda Nawawi Arief, 1996, Bunga Rampai Kebijakan Hukum Pidana, Citra Aditya, Bandung, h. 29 
pidana termasuk pula kebijakan dalam menangani dua masalah sentral di atas, harus pula dilakukan dengan pendekatan yang berorientasi pada kebijakan (policy oriented approach).

Sama halnya dengan Sudarto yang berpendapat bahwa dalam menghadapi dua masalah sentral di atas, maka terhadap masalah sentral yang pertama harus diperhatikan hal-hal yang pada intinya: ${ }^{7}$

1. Penggunaan hukum pidana harus memperhatikan tujuan pembangunan nasional, yaitu perwujudan masyarakat adil dan makmur yang merata materiil dan spirituil berdasarkan Pancasila; sehubungan dengan ini maka (penggunaan) hukum pidana bertujuan untuk menanggulangi kejahatan dan mengadakan penggugeran terhadap tindakan penganggulangan itu sendiri, demi kesejahteraan dan pengayoman masyarakat;

2. Perbuatan yang diusahakan untuk dicegah atau ditanggulangi dengan hukum pidana harus merupakan perbuatan yang tidak dikehendaki, yaitu perbuatan yang mendatangkan kerugian (materiil dan sipirutil) atas warga masyarakat;

3. Penggunaan hukum pidana harus pula memperhitungkan prinsip biaya dan hasil (cost and benefit principle);

4. Penggunaan hukum pidana harus pula memperhatikan kapasitas atau kemampuan daya kerja dari badan badan penegak hukum, yaitu jangan sampai ada kelampauan beban tugas (overbelasting).

Pendapat kedua ahli di atas didukung pula oleh beberapa pemikiran yang pernah berkembang pada penyelenggaraan Simposium Pembaharuan Hukum Pidana Nasional tahun tahun 1980. Dalam satu laporannya, ditegaskan bahwa "masalah kriminalisasi dan dekriminalisasi atas suatu perbuatan haruslah

${ }^{7}$ Sudarto, 1977, Hukum dan Hukum Pidana, Alumni, Bandung, h. 44-48 
sesuai dengan politik kriminal yang dianut oleh bangsa Indonesia, yaitu sejauhmana perbuatan tersebut bertentangan dengan nilai nilai fundamental yang berlaku dalam masyarakat dan oleh masyarakat dianggap patut atau tidak patut dihukum dalam rangka menyelenggarakan kesejahteraan masyarakat". Simposium merumuskan beberapa langkah perumusan tindak pidana yang mesti diperhatikan, yakni :

a. Apakah perbuatan itu tidak disukai atatu dibenci oleh masyarakat karena merugikan, atau dapat merugikan, mendatangkan korban atau dapat mendatangkan korban;

b. Apakah biaya kriminalisasi seimbang dengan hasilnya yang akan dicapai, artinya costpembuatan undang undang, pengawasan dan penegakan hukum, serta beban yang dipikul oleh korban, pelaku dan pelaku kejahatan itu sendiri harus seimbang dengan situasi tertib hukum yang akan dicapai.

c. Apakah akan makin menambah beban aparat penegak hukum yang tidak seimbang atau nyata-nyata tidak dapat diemban oleh kemampuan yang dimilikinya.

d. Apakah perbuatan-perbuatan itu menghambat atau menghalangi cita-cita bangsa, sehingga merupakan bahaya bagi keseluruhan masyarakat.

Sama halnya dengan masalah pemilu, bahwa penyelenggarannya tidak berdiri sendiri atau bersifat fakultatif, akan tetapi merupakan bagian dari politik sosial suatu bangsa, dan karena itu diperlukan adanya pengamanan melalui kebijakan hukum atau politik hukum, yang dalam hal ini dapat berupa penggunaan sarana hukum administrasi maupun sarana hukum pidana (penal). 
Menganalisis rumusan tindak pidana dan pola ancaman pidana dalam Undang-Undang Nomor 1 Tahun 2015 tentang Pemilihan Kepala Daerah jo Undang-Undang Nomor 8 Tahun 2015 memang belum dikatakan sempurna atau masih terdapat beberapa kelemahan jika dianalisis dari pendekatan kebijakan hukum pidana. Walaupun demikian haruslah diakui bahwa undang undang pemilu tersebut digunakan memang merupakan sebuah produk politik yang telah mengalami proses legislasi secara matang di lembaga legislatif.

Padahal jika memang kebijakan hukum pidana di dalam undang undang pemilu, bahkan juga untuk undang undang lainnya yang cenderung menggunakan sarana hukum pidana sebagai pelindung hendak terpadu (integrated), maka mungkin menarik untuk disikapi pemikiran Bassiouni bahwa seharusnya dipertimbangkan sebagai salah satu scientific device dan digunakan sebagai alternatif dari pendekatan dengan penilaian emosional (the emosionally laden value judgment approach) oleh kebanyakan badan-badan peradilan. ${ }^{8}$

Menurut Bassiouni, perkembangan 'a policy oriented approach' ini lamban datangnya, karena proses legislatif belum siap untuk pendekatan yang demikian. Proses kriminalisasi yang berlangsung terus tanpa suatu evaluasi mengenai pengaruhnya terhadap keseluruhan sistem mengakibatkan timbulnya : ${ }^{9}$

1. Krisis kelebihan kriminalisasi (the crisis of over criminalization) dan;

2. Krisis kelampauan batas dari hukum pidana (the crisis of overreach of the criminal law)

Lemahnya ketentuan tindak pidana pemilu dalam Undang-

${ }^{8}$ Bassiouini, M. Chief, 1978, Substantive Criminal Law, h. 82-84

${ }^{9}$ Ibid., h. 84 
Undang Nomor 1 Tahun 2015 tentang Pemilihan Kepala daerah jo Undang-Undang Nomor 8 Tahun 2015 menyebabkan penegakan hukum tindak pidana pemilu menjadi sangat lemah. Buktinya masih ada saja pelanggaran money politic pada setiap penyelenggaraan pemilu.

Problem penegakan hukum pidana pemilu setidaknya dapat dilihat dari masing-masing komponen dalam sistem hukum yang secara langsung berpengaruh terhadap penegakan hukum. Lawrence M. Friedman menilai, berhasil atau tidaknya hukum ditegakkan tergantung pada tiga komponen sistem hukum. Pertama, substansi hukum (legal substance). Substansi hukum adalah aturan, norma, dan pola prilaku nyata manusia yang berada dalam sistem itu. ${ }^{10}$

Kedua, struktur hukum (legal structure) atau struktur sistem hukum. Friedman menyebutnya sebagai kerangka atau rangka atau bagian yang tetap bertahan atau bagian yang memberi semacam bentuk dan batasan terhadap keseluruhan. ${ }^{11}$ Keberadaan struktur hukum sangat penting, karena betapapun bagusnya norma hukum, namun jika tidak ditopang aparat penegak hukum yang baik, penegakan hukum dan keadilan hanya sia-sia. Ketiga, budaya hukum (legal culture). Kultur hukum adalah opini-opini, kepercayaan-kepercayaan (keyakinan-keyakinan), kebiasaankebisaaan, cara berfikir, dan cara bertindak, baik dari para penegak hukum maupun dari warga masyarakat tentang hukum dan berbagai fenomena yang berkaitan dengan hukum. ${ }^{12}$

Berangkat dari tiga indikator tersebut, belum efektifnya

${ }^{10}$ Lawrence M. Friedman, American Law: An Introduction, Second Edition, Penerjemah : Wishnu Basuki, 2001, Tatanusa, Jakartam, h.. 7

${ }^{11}$ Ibid., h. 12.

${ }^{12}$ Achmad Ali, 2012, Menguak Teori Hukum (Legal Theory) dan Teori Peradilan (Judicialprudence) Termasuk Interprestasi Undang-Undang (Legisprudence), Volume 1, Kencana, Jakarta, h. 204 
penegakan hukum pidana pemilu juga tidak dapat dilepaskan dari masalah yang terdapat dalam peraturan perundang-undangan pemilu, khususnya terkait ancaman pidana pada tindak pidana pemilu;masalah aparat penegakan hukum yang terdiri dari pengawas pemilu, kepolisian, kejaksanaan dan hakim pada pengadilan Negeri dan Pengadilan Tinggi; dan budaya hukum penyelenggaraan pemilu yang jauh dari harapan karena masih saja ditemui penyimpangan di sana sini.

Pada taraf norma, peraturan perundang-undangan sebagaimana diulas pada bagian sebelumnya masih lemah sanksi hukumnya, bahkan tidak di atur ancaman pidananya untuk perbuatan tertentu, seperti money politic. Bahkan hukum formil yang ada tidak cukup memadai untuk menegakkan hukum pidana pemilu secara efektif, salah satunya waktu penanganan tindak pidana pemilu yang begitu cepat. Sementara pada level struktur, penegak hukum dihadapkan pada berbagai persoalan baik dari dalam maupun luar pribadinya, seperti netralitas yang kadang belum dilaksanakan sepenuhnya. Sedangkan pada ranah budaya hukum, pihak-pihak berkepentingan, terutama peserta pemilu masih berkecenderungan untuk "mengakali" aturan yang ada sehingga dapat berkelit dari tuntutan hukum.

Masyarakat politik bukannya membangun kesadaran akan perlunya mengikuti pemilihan sesuai aturan-aturan yang ada, melainkan justru membangun sikap culas atas aturan yang ada. Tiga persoalan penegakan hukum pidana pemilu tersebut berkelindan sedemikian rupa sehingga penegakan hukum pemilu benar-benar lumpuh (sekedar tidak mengatakan mati suri). Akibatnya, perkara-perkara dugaan tindak pidana pemilu pun tidak tertangani dengan baik 
Menurut Achmad Sulchan penegakan hukum dapat pula menyangkut kegiatan tindakan terhadap setiap pelanggaran perkara pidana pemilihan atau penyimpangan terhadap peraturan perundang-undangan pemilihan melalui proses pidana yang melibatkan peran aparatt penegak hukum Badan Pengawas Pemilu (Bawaslu), Komisi Pemilihan Umum (KPU), kepolisian, kejaksaan, pengadilan, dan lembaga pemasyarakatan (LP), dan atau advokat/pengacara. ${ }^{13}$

Para penegak hukum tersebut dapat sebagai orang atau unsur manusia dengan kualitas, kualifikasi, dan kultur kerjanya masing-masing. Namun juga dapat sebagai aktor, pelaku, pejabat, atau aparat penegak hukum dilihat sebagai institusi, badan, atau organisasi dengan kualitas birokrasi. Para profesi hukum itu antara lain meliputi politisi (legislator), perancang hukum (legal drafter), pengacara (advokat), notaris, pejabat pembuat akta tanah, polisi, jaksa, panitera, hakim, dan arbiter atau wasit.Penegakan hukum juga larus diimbangi dengan kepemimpinan dalam semua tingkatan yang remenuhi syarat sebagai pemimpin yang diharapkan dapat menjadi Penggerak yang efektif untuk tindakan-tindakan penegak hukum j'ang pasti dan juga diharapkan dapat menjadi teladan bagi lingkungan serta taat aturan. ${ }^{14}$

\section{Hambatan yang dihadapi Penyidik dalam Penanganan Tindak Pidana Pemilihan Kepala Daerah}

1. Terbatasnya waktu penanganan tindak pidana pemilihan kepala daerah

Pada Pasal 146 Undang-Undang Nomor 1 Tahun 2015 tentang

\footnotetext{
${ }^{13}$ Achmad Sulchan, 2016, Perkara Pidana Pemilihan Umum yang Bernilai Keadilan, Semarang, Sint Publishing, h. 3

${ }^{14}$ Ibid., h. 3
} 
disebutkan bahwa Penyidik Kepolisian Negara Republik Indonesia menyampaikan hasil penyidikannya disertai berkas perkara kepada penuntut umum paling lama 14 (empat belas) hari sejak laporan diterima.Dalam hal hasil penyidikan belum lengkap, dalam waktu paling lama 3 (tiga) hari penuntut umum mengembalikan berkas perkara kepada Penyidik Kepolisian Negara Republik Indonesia disertai petunjuk tentang hal yang harus dilakukan untuk dilengkapi. Penyidik Kepolisian Negara Republik Indonesia dalam waktu paling lama 3 (tiga) hari sejak tanggal penerimaan berkas harus sudah menyampaikan kembali berkas perkara tersebut kepada penuntut umum. Penuntut umum melimpahkan berkas perkara kepada Pengadilan Negeri paling lama 5 (lima) hari sejak menerima berkas perkara.

Berdasarkan ketentuan tersebut penyidik mermpunyai waktu 14 (empat belas) hari menyampaikan hasil penyidikan tindak pidana pemilu dan 3 (tiga) hari menyampaikan kembali berkas perkara yang harus dilengkapi sesuai dengan petunjuk penuntut umum. Waktu yang diberikan kepada penyidik dalam penanganan tindak pidana pemilu tersebut sangat terbatas.

Untuk menyelesaikan berkas penyidikan dibutuhkan proses yang menyita waktu. Proses yang harus dilalui dalam penyidikan cukup panjang antara lain pemanggilan, pemeriksaan, penggeledahan, penyitaan, penangkapan, penahanan, penyelesaian berkas, dan penyerahan berkas perkara. Masing-masing tahap yang harus dilalui dibutuhkan waktu yang cukup agar dapat dilaksanakan dengan baik.

a. Pemanggilan

Hambatan yang dihadapi dalam proses pemanggilan antara lain terpanggil tidak berada di tempat, sengaja tidak menghadap 
sesuai dengan waktu yang ditentukan dalam surat panggilan.

b. Pemeriksaan

Hambatan yang dihadapi dalam proses pemeriksaan yaitu tersangka berbelit-belit memberikan keterangan sehingga penyidik kesulitan mengungkap perkara dan menemukan bukti permulaan yang cukup.

c. Penggeledahan

Hambatan dalam penggeledahan antara lain : subyek penggeledahan menghalang-halangi penggeledahan, hilangnya obyek penggeledahan.

d. Penyitaan

Hambatan dalam penyitaan yaitu prosedur penyitaan yang memakan waktu, yakni penyitaan dilakukan dengan surat perintah dan surat ijin/surat ijin khusus penyitaan dari Ketua Pengadilan Negeri

e. Penangkapan

Hambatan dalam penangkapan yaitu obyek penangkapan melarikan diri, berada di luar kota, sehingga memakan waktu

f. Penahanan.

g. Penyelesaian berkas

Hambatan penyelesaian berkas yaitu keterbatasan personil, sarana dan prasarana sedangkan penyelesaian berkas waktunya sangat terbatas.

h. Penyerahan berkas perkara

Waktu penyerahan berkas sangat tergantung dari rangkaian proses penyidikan. Jika proses penyidikan terhambat maka penyerahan berkas juga akan mengalami hambatan

Pasal 146 ayat (3)Undang-Undang Nomor 1 Tahun 2015 tentang Pemilihan Umum Kepala Daerah jo Undang-Undang Nomor 
8 Tahun 2015 menyebutkan bahwa Penyidik Kepolisian Negara Republik Indonesia dalam waktu paling lama 3 (tiga) hari sejak tanggal penerimaan berkas harus sudah menyampaikan kembali berkas perkara tersebut kepada penuntut umum. Berdasarkan ketentuan tersebut waktu yang diberikan kepada penyidik untuk melengkapi berkas penyidikan sesuai petunjuk umum sangat singkat.

Hambatan keterbatasan waktu tersebut masih ditambah jika petunjuk penuntut umum sulit untuk dipenuhi. Untuk memenuhi petunjuk penuntut umum kadang dibutuhkan proses penyidikan lanjutan seperti meminta keterangan saksi dan keterangan ahli. Sedangkan untuk melaksanakan kegiatan pemeriksaan saksi dan ahli kadang menemui hambatan dalam pemanggilan seperti tersebut di atas.

1. Hambatan teknis penyelesaian administrasi

Penyelesaian tindak pidana pemilu pada dasarnya sama seperti penyelesaian tindak pidana pada umumnya. Penyelesaian penyidikan tindak pidana tidak dapat dilepaskan dari administrasi berupa berkas-berkas yang harus dilengkapi. Dalam menyelesaikan administrasi terkadang ditemui hambatan teknis, seperti penandatanganan berkas oleh pimpinan dan atau yang berwenang menemui hambatan karena yang bersangkutan tidak berada di tempat karena suatu hal seperti berada di luar kota yang tidak memungkinkan penandatanganan berkas segera.

\section{PENUTUP}

\section{Kesimpulan}

Peranan Penyidik Polres Pemalang dalam penanganan tindak pidana Pemilihan kepala daerah yaitu sebagai penyidik adanya 
dugaan tindak pidana pemilihan kepala daerah. Penanganan tindak pidana pemilihan kepala daerah dilaksanakan berdasarkan laporan panitia pengawas setelah melalui pembahasan dalan sentra penegakan hukum terpadu (Sentra Gakkumdu) terhadap laporan pelanggaran pemilihan kepala daerah.

\section{Saran}

Kebijakan kriminal (criminal policy) hendaknya dilakukan secara lengkap terhadap perbuatan tertentu, apalagi terhadap tindak pidana khusus yang lemah apabila diterapkan KUHP yang merupakan ketentuan pidana umum, demikian pula terhadap tindak pidana pemilu disamping mengatur perbuatan yang dapat dipidana hendaknya dicantumkan pula ancaman pidananya. Hal ini penting agar kebijakan kriminal dapat mencapai tujuan yang diharapkan. 


\section{DAFTAR PUSTAKA}

\section{A. Buku}

Achmad Sulchan, 2016, Perkara Pidana Pemilihan Umum yang Bernilai Keadilan, Semarang, Sint Publishing.

Ahmad Wardi Muslich, 2004, Pengantar dan Asas Hukum Pidana Islam, Sinar Grafika, Jakarta

Achmad Ali, 2012, Menguak Teori Hukum (Legal Theory) dan Teori Peradilan (Judicialprudence) Termasuk Interprestasi Undang-Undang (Legisprudence), Volume 1, Kencana, Jakarta

Barda Nawawi Arief 1996, Bunga Rampai Kebijakan Hukum Pidana, Citra Aditya Bakti, Bandung

Djanedjri M, 2009, Pelanggaran dan Sengketa Pemilu, Harian Seputra Indonesia, Jakarta.

Jan Remmelink, 2003, Hukum Pidana - Komentar Atas Pasal-Pasal Terpenting Dari KUHP Belanda dan Padanannya Dengan KUHP Indonesia, Gramedia, Pustaka Utama, Jakarta

Jimly Asshiddiqie, 2007, Pokok-Pokok Hukum Tata Negara Indonesia Pasca Reformasi, BIP, Jakarta

Lawrence M. Friedman, American Law: An Introduction, Second Edition, Penerjemah : Wishnu Basuki, 2001, Tatanusa, Jakarta

Mahmud Mulyadi, 2006, Kebijakan Penanggulangan Kejahatan Kekerasan (Studi di Kota Palembang), Disertasi

Soejono; H. Abdurrahman, 1997, Metode Penelitian Hukum.Rineka Cipta, Jakarta

Sudarto, 1990, Hukum Pidana I,Yayasan Sudarto Fakultas Hukum Undip, Semarang.

Sedarmayanti; Syarifudin Hidayat, 2002,Metodologi Penelitian, Mandar Maju, Bandung. 
Soewoto Mulyosudarmo, 2004, Pembaharuan Ketatanegaraan Melalui Perubahan Konstitusi, Asosiasi Pengajar HTN dan HAN dan In-TRANS, Malang

Suryono Sutarto. 1991. Hukum Acara Pidana, Badan Penerbit Universitas Diponegoro, Semarang.

Suryono Sutarto; Sudarsono, 2001, Hukum Acara Pidana Jilid II, Fakultas Hukum Universitas Muria, Kudus

Sayyidatul Insiyahm Xavier Nugraha, Shevierra Danmadiyah, Pemilihan Kepala Daerah Oleh Dewan Perwakilan Rakyat Daerah: Sebuah Komparasi Dengan Pemilihan Secara Langsung Oleh Rakyat, Supremasi Hukum : Jurnal Penelitian Hukum, Vol. 28, No. 2, Agustus 2019;

Teguh Prasetyo, 2005, Hukum Pidana Materil Jilid I,Kurnia Kalam, Yogyakarta

Topo Santoso. 2003. Membumikan Hukum Pidana Islam: Penegakan Syariat dalam Wacana dan Agenda, cet. ke-1, Gema Insani Press, Jakarta

Trisno Raharjo. 2011. Mediasi Pidana Dalam Sistem Peradilan Pidana.Yogyakarta. Mata Padi Pressindo

\section{B. Perundang - Undangan}

Undang-Undang Nomor 1 Tahun 1964 tentang Kitab Undang-Undang Hukum Pidana

Undang-Undang Nomor 8 Tahun 1981 tentang Kitab Undang-Undang Hukum Acara Pidana.

Undang-undang Nomor 1 Tahun 2015 tentang Penetapan Peraturan Pemerintah Pengganti Undang-Undang Nomor 1 Tahun 2014 Tentang Pemilihan Gubernur, Bupati, dan Walikota Menjadi Undang-Undang sebagaimana diubah dengan Undang-Undang Republik Indonesia Nomor 8 Tahun 2015 